\title{
XLV. On shooting stars
}

\section{Sir J.W. Lubbock Bart. F.R.S.}

To cite this article: Sir J.W. Lubbock Bart. F.R.S. (1849) XLV. On shooting stars, Philosophical Magazine Series 3, 35:237, 356-357, DOI: 10.1080/14786444908562702

To link to this article: http://dx.doi.org/10.1080/14786444908562702

$$
\text { 册 Published online: } 30 \text { Apr } 2009 .
$$

6 Submit your article to this journal $\pi$

LII Article views: 2

Q View related articles $₫$ 


\section{[ 356 ] \\ XLV. On Shooting Stars. \\ By Sir J. W. Luввоск, Bart., F.R.S.*}

QOME time since, in a paper in the Philosophical Magazine, $D$ I ventured to suggest that the disappearance of shooting stars might be occasioned by their passing into the earth's shadow, or in other words, by being eclipsed. Lately, in looking over the Astronomische Nachrichten, I found in No. 614, in a paper entitled "Ueber eine Längenbestimmung aus den August-Sternschuppen," 1847, by M. Weyer, three observations of shooting stars, which might, supposing their distance from the earth's surface as given in that paper sufficiently accurate, serve to test in those instances the truth of my hypothesis. Accordingly I requested Mr. Farley to calculate the distance of the bodies, and the following tables exhibit the results obtained, and the data, as furnished by the tables in the Ast. Nach. They do not appear to be favourable to the hypothesis above referred to. The notation is as follows, conformably to that of my preceding paper:-

$R=$ earth's semidiameter $=3958$ miles.

$a=$ azimuth of shooting star - azimuth of sun ; reckoned from the south meridian westward.

$\zeta=$ apparent zenith distance of shooting star.

$\rho=$ distance of shooting star from the spectator.

$\theta=$ depression of sun's centre, so that $90^{\circ}+\theta=$ sun's zenith distance.

\begin{tabular}{|c|c|c|c|c|c|c|}
\hline \multirow{2}{*}{1847.} & \multirow{2}{*}{$\begin{array}{l}\text { Mean time } \\
\text { at } \\
\text { Hamburg. }\end{array}$} & \multirow{2}{*}{$\begin{array}{l}\text { Place of } \\
\text { dísap- } \\
\text { pearance. }\end{array}$} & \multirow{2}{*}{$\begin{array}{l}\text { Mean time } \\
\text { at Pa- } \\
\text { penburg. }\end{array}$} & \multirow{2}{*}{$\begin{array}{c}\text { Place of } \\
\text { dis- } \\
\text { appearance. }\end{array}$} & \multicolumn{2}{|c|}{$\begin{array}{l}\text { Distance from the earth's } \\
\text { surface in }\end{array}$} \\
\hline & & & & & German miles. & English miles. \\
\hline Aug. 10.. & $\begin{array}{ccc}\mathrm{h} & \mathrm{m} & \mathrm{s} \\
10 & 54 & 2 \\
10 & 58 & 43 \\
11 & 40 & 25\end{array}$ & $\begin{array}{l}\text { Herculis } \\
\text { Lyra ... } \\
\text { Lyræ ... }\end{array}$ & $\mid \begin{array}{ccc}\mathrm{h} & \mathrm{m} & \mathrm{g} \\
10 & 43 & 53 \\
10 & 48 & 34 \\
11 & 30 & 16\end{array}$ & $\begin{array}{l}\text { ๔ Pegasi ... } \\
\alpha \text { Androm. } \\
\beta \text { Arietis ... }\end{array}$ & $\begin{array}{l}12 \\
18 \\
10\end{array}$ & $\begin{array}{l}55 \\
83 \\
46\end{array}$ \\
\hline
\end{tabular}

In order to estimate the effect which an error in the assumed place of disappearance would have upon $\rho$, it has been calculated upon three different hypotheses:-

1. Supposing the shooting star to have disappeared at Papenburg, having the same R.A. and Dec. as the star indicated in the Ast. Nach.

2. Supposing the place so assumed to be in error $3^{\circ}$ or $12^{\mathrm{m}}$ in R.A., and the Dec. to be correct.

3. Supposing the place assumed to be in error $3^{\circ}$ in Dec. and the R.A. to be correct.

* Communicated by the Author. 
The last column contains the value of $g$ as obtained from the distance from the earth's surface given in the Ast. Nach. For the purpose of comparison, it will be seen that much greater errors than those $I$ have assumed in the place of the shooting star's disappearance would be required to conciliate the two results.

We found for the instant of disappearance and for Papenburg, -

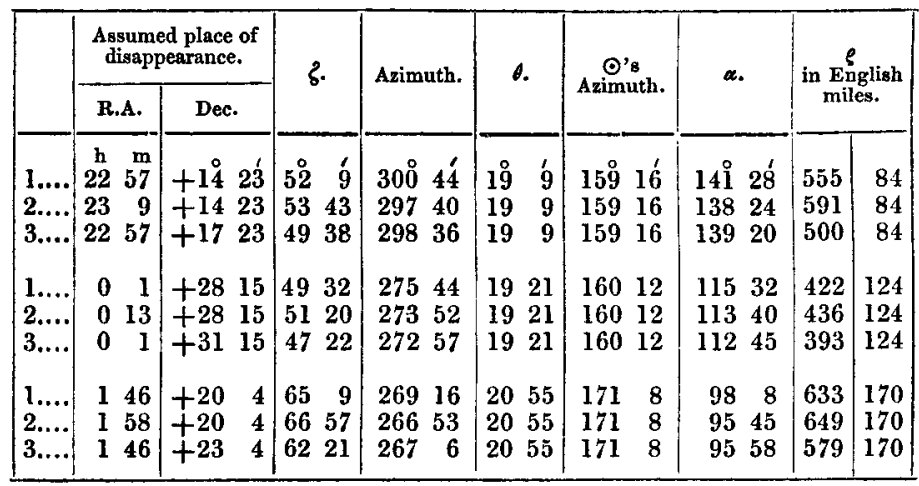

It seems very desirable to procure other observations of this kind made by two or more persons, having their time sufficiently accurate to be able to identify the meteor, and by each noting as accurately as possible the place of disappearance, so that they may be enabled through the parallax of the body to determine its distance from the earth. I do not see in what manner isolated observations by one person can in the present state of the subject tend to elucidate this interesting question. The paper in the Ast. Nach., to which I have referred, affords ample evidence that such combined efforts would in all probability be attended with success. The determination of the distance of the body by means of its parallax is of course independent of any hypothesis as to its nature, and may therefore serve as a guide in any reasoning upon that point.

XLVI. Remarks on the Weather during the Quarter ending September 30, 1349. By James Glaisher, Esq., F.R.S., F.R.A.S., and of the Royal Observatory, Greenzoich*.

A MORE than ordinary interest is attached to the meteorA ology of the present year, and in particular to that part of the year just passed, owing to the presence of cholera as an - Communicated by the Author. 